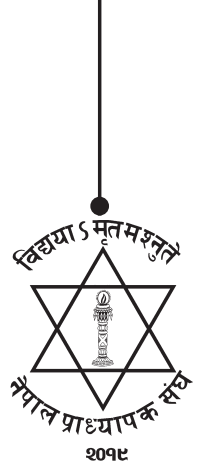

NJ: NUTA

\title{
E- Waste Management: An Emerging Challenge in Nepal
}

\author{
Bishnu B. Khatri \\ Lecturer, Central Department of Rural Development \\ Tribhuvan University (TU), Kathmandu, Nepal \\ Email for correspondence: khatri.bishnu@cdrd.edu.np, khatri.bishnu@gmail.com
}

\begin{abstract}
E-waste is one of the fastest growing waste streams, globally and volume of E-waste has been increasing day by day in developing countries, like Nepal. The aim of this paper is to assess the situation of E-waste in Nepal and its growing concerns of management. The study has utilized secondary information generated by published and unpublished documents. The paper revealed that socio-economic development and technological advancement are the main drivers of increasing trend of E-waste. The increasing trend of e-waste generation and lack legal provision in Nepal has come up as one of the major environmental problems and challenges for its proper management. Considering its adverse potential eco-toxicological impacts, the legal instrument of E-waste management is urgently needed addressing e-waste handling, storage, transportation, recycling, and final disposal.
\end{abstract}

Keywords: E-waste, Management, Challenge, Nepal

\section{Introduction}

Electronic waste or e-waste is the term given to describe any electronic product, or product containing electrical components, that has reached the end of its usable life cycle (Sthiannopkao \& Wong 2013). E-waste, also known as Waste Electrical and Electronic Equipment (WEEE) can be characterized as development-related waste. Globally, E-waste is one of the fastest growing waste streams, and according to Hotta et al. (2008), "Asia has become the engine of world waste generation". The issues of E-wastes is no longer confined as a domestic issue of a country but has international dimension as electronic products and E-waste are commonly traded across national boundaries.

E-waste production is increasing at an alarming rate, especially in developing countries which currently do not have the proper funds or resources to dispose of it properly on one hand. On other hand, technology is advancing at an exponential rate; new electronics are faster, smaller, and more convenient to use. What about that old phone, computer, or camera that is discarded because there are newer and fresher alternatives? We live in a consumer driven society that is constantly buying, upgrading, and replacing current technology. The problem of e-waste is escalating rapidly through increased production of electronics and e-waste exportation from developed countries to developing countries because of the beneficial economic incentives that it provides. The total amount of e-waste 
produced has reached approximately 41 million ton in 2014 and increasing at a rate of 3-5\% every year (Kumar, et al. (2017).

E-waste is considered harmful mainly because of various toxic chemicals found in such waste. The non-recyclable concentrated lead, cadmium and beryllium are found in high amount in these waste products. Burning these trashes can create health hazards and leave poisonous chemicals in the environment. Increasing use of electronic devices like mobile phone, telephone, radio, television, computer, refrigerators, air coolers, and other electronic gadgets is contributing to more e-waste production in the country. Therefore, the need for proper e-waste management thus seems quite important in the country. The paper intends to assess the situation of E-waste in Nepal and its growing concerns of management.

\section{Present Status: An Emerging Challenges}

It is estimated that globally 20 50 million tonnes of e-waste are discarded annually of which Asian countries account for about 12 million tonnes (Greenpeace International, 2005). Considering populous India and China, though the per capita e-waste production is estimated to be below $1 \mathrm{~kg}$ per year, the total absolute volume of e-waste generated is enormous (Widmer et al., 2005). Industrialized and developed nations are the main producers of e-waste. According to the USEPA (2009), the US is the largest e-waste producer in the world today, generating 3.16 million tons in 2008. Electrical and electronic goods contain a variety of metals, many of which are toxic to humans and ecosystems. More than $60 \%$ of e-waste consists of these different metal ions and about $2.7 \%$ are toxic metals (Widmer et al., 2005). The proper management (collecting, storage, recycling, disposing) of these wastes is important because of hazardous chemicals in the waste such as aluminum (Al), arsenic (As), bismuth $(\mathrm{Bi})$, cadmium $(\mathrm{Cd})$, chromium $(\mathrm{Cr})$, mercury $(\mathrm{Hg})$, nickel $(\mathrm{Ni})$, lead $(\mathrm{Pb})$ and antimony $(\mathrm{Sb})$. According to Department of Environment in 2017 showed that e-waste collection in the year 2017 might reach 17,730 metric tonnes (The Himalayan Times, 2017).

The utilization of electronics in our everyday life is almost as important as our very existence in this fast-paced globalized world, but the effective management and long term effects of the resultant waste has not fully been grasped by consumers. This is mainly due to the fact that there is only an emerging body of knowledge on e-waste in the field of waste management; and a limited data on e-waste generation among developed and developing nations. Additionally, e- waste is perceived and managed differently amongst different countries. Therefore, understanding the key concepts of e-waste management and the relationships between the economic impact of e-waste and its negative effects on the host community will serve as a base for better environmental and socially friendly practices for e-waste management. Imports of electronic products are accelerating day by day in Nepal. In addition, E-waste management is still an issue not given a required priority by government in Nepal. In the recent years, the consumption of electronic items has significantly grown but due to the lack of guidelines and regulations regarding proper disposal of those electronic items after their lifetime is over, public remain vulnerable to the contamination caused by emissions from those devices and equipments. In this context, Nepal is sure to face a hard time in the coming days, since this kind of waste cannot be recycled and are too dangerous to be managed at landfill sites. There is a pressing need to address ewaste management in Nepal. 


\section{Current Provision of Nepal}

Nepal's constitution has reserved the right to survive in a clean environment as fundamental right of any citizen. The Environment Protection Act, 2053 (1997) has been formulated and implemented effective from the Jan 30, 1997 ( $17^{\text {th }}$ Magh 2053 B.S). The preamble of the act is to expedite to make legal provisions in order to maintain clean and healthy environment by minimizing, as far as possible, adverse impacts likely to be caused from environmental degradation on human beings, wildlife, plants, nature and physical objects; and to protect environment with proper use and management of natural resources, taking into consideration that sustainable development could be achieved from the inseparable inter-relationship between the economic development and environment protection. The act has provisioned for Initial Environmental Examination (IEE) and Environmental Impact Assessment (EIA) to be performed by a proponent. The provision for prevention and pollution control has been stated in the Act. The provision for the corresponding Environment Inspector with function, duties and powers has been defined in the Act. The Nepal government has been dealing with every environment related issues under Environment Protection Act 1997, which does not mention anything about e-waste management. For the growing concern of e-waste management, Nepal's government legal provision is absent at present. Consequently, developing countries like Nepal are in a vulnerable situation due to their lack of inventory data, waste management policies and advanced technology for environmentally sound management.

\section{Conclusions}

E-waste is being generated and gathered at a rapid rate in developing countries around the world. This e-waste recycling issue needs to be addressed to reduce the harmful resulting effects that the toxic chemicals in e-waste have on environment and human health. Nepal is sure to face a hard time in the coming days, since this kind of waste cannot be recycled and are too dangerous to be managed at landfill sites. Industrial management of these wastes also seems very challenging in Nepal. The biggest problem regarding e-waste is that the Government of Nepal does have any laws and set of rules regarding the proper management of hazardous e-wastes. The government has been dealing with every environment related issues under Environment Protection Act 1997, which does not mention anything about e-waste management.

\section{References}

Department of Environment, Government of Nepal. (1997). Environment protection act 2053. Kathmandu: Department of Environment, GoN.

Greenpeace International. (2005). The e-waste problem. Available at: http://www.greenpeace.org/ international/en/campaigns/toxics/electronics/the-e-waste-problem/ (Retrieved on 27 Dec 2011).

Hotta, Y., Elder, M., Mori, H. \& Tanaka, M. (2008). Policy considerations for establishing an environmentally sound regional material flow in East Asia. The Journal of Environment and Development 17, 1, 26-50.

Kumar, A., Holuszko M. \& Espinosa, D.C.R. (2017). E-waste: An overview on generation, collection, legislation and recycling practices. Res Conser and Recyc 122: 32-42. 
Sthiannopkao, S. \& Wong, M. H. (2013). Handling e-waste in developed and developing countries: Initiatives, practices, and consequences. Sci of the Tot Environ 463: 1147-1153.

The Himalayan Times (November 12, 2017). Nepal lacks e-waste management laws. The Himalayan Times, Daily Newspaper, Kathmandu, Nepal.

United States Environmental Protection Agency, USEPA. (2009). Hazardous waste report: instructions and form [Internet]. Washington, D.C.: United States Environmental Protection Agency. Available from: http://www3.epa. gov/epawaste/inforesources/data/br09/br2009rpt.pdf.

Widmer, R., Oswald-Krapf, H., Sinha-Khetriwal, D., Schnellmann, M., Böni, H., (2005).Global perspectives on e-waste. Environmental Impact Assessment Review, 25, 436-458. 